\title{
CONTRIBUTION OF INTERNATIONAL TRADE AND CAPITAL ACCUMULATION TO ECONOMIC GROWTH OF THAILAND DURING THE LAST HALF OF THE $20^{\mathrm{TH}}$ CENTURY
}

\author{
Nguyen Minh Duc \\ NongLam University,nguyenminhducts@gmail.com \\ (Received: 19/07/2013; Revised: 11/12/2013; Accepted: 20/01/2014)
}

\begin{abstract}
The present paper examines the links between international trade, capital and economic growth in Thailand from 1950 to 2000 in an applied growth model including exchange rate as a control variable. Prior to 1980 the elasticity of per capita income with respect to trade was $-0.2 \%$ switching to $0.07 \%$ in 1980 in line with the change from resource exports and import substitution to manufactured exports. The exchange rate elasticity of per capita income prior to 1980 was $0.4 \%$ switching to $-0.2 \%$ consistent with the move to a floating exchange rate. Results confirm the overriding theoretical importance of investment to economic growth.
\end{abstract}

Keywords: international trade, neo-classical growth, time series analysis, Thailand JEL code: F43, O53.

\section{Introduction}

The role of trade in economic growth is a recurring issue, and countries exporting manufactures seem to grow faster than those exporting natural resource products. Thailand presents an interesting study with its market economy discussed by Yamada (1998) as the share of agriculture in GDP fell from $37 \%$ in 1961 to $13 \%$ in 1991. Nevertheless, labor intensive agriculture still employs the majority of the labor force and receives the third largest government budget allocation.

From agricultural base, Thailand has become one of the more diversified economies in Southeast Asia (The Economist, 2004). Import substitution policy of the $1970 \mathrm{~s}$ switched to manufactured export promotion in the 1980s based on labor intensive products such as textiles and apparel. Since 1990 the fastest growth has been in high technology products such as computer accessories and motor vehicle parts. Industrial growth is based on imports of capital goods, intermediate goods, raw materials, and fuels. This half century of varied growth provides a laboratory to examine the empirical links between trade openness and economic growth. The present paper examines contribution of international trade, capital accumulation to economic growth in Thailand during the last half of the $20^{\text {th }}$ century.

\section{The literature and present model}

Regarding the evidence on trade and growth, Karras (2003) investigates data for 161 countries and finds trade has a positive, permanent, and sizable effect on growth. Panagariya (2004) finds sustained rapid growth cannot be achieved without rapid trade growth. Rassekh (1992) 
shows that poorer countries increase their trade faster than high income countries and faster trade expansion implies more rapid growth across 19 OECD countries. Deme and Homaifar (2001) find a long run positive relationship between imports and growth for Japan. Olufemi (2004) uncovers a unidirectional relationship between trade and growth for Nigeria and shows the effect depends on the level of economic development.

In contrast, Levine and Renelt (1992), Sala-i-Martin (1997), and Masters and McMillan (2001) find trade has not been a robust determinant of recent economic growth. Lutz (2001) uncovers only a weak and inconsistent link for industrialized countries. Dowrick and Golley (2004) find specialization in primary exports slows growth with the benefits of trade going mostly to developed countries since 1980 .

Ades and Glaeser (1999), Frankel and Romer (1999), Alesina, Spolaore, and Wacziarg (2000, 2003), and Frankel and Rose (2002) find access to larger export markets fosters growth, and Alcalá and Ciccone (2003) find trade matters more for smaller economies. In an analysis of 55 developing countries, McCarthy, Taylor and Talati (1987) find trade is not related to growth for developing countries with commodity trade surpluses offsetting imports of capital goods and services. Frankel and Cavallo (2004) find trade makes countries less vulnerable to sudden stops and currency crashes.

The present model examines the impact of a trade index, total trade relative to income, on per capita income. The trade index is export revenue plus import spending relative to gross domestic product. The exchange rate is included as a control variable to isolate its impact. The capital labor ratio is the foundation of neoclassical economic growth and is included as a control variable.
Start with the neoclassical production function, $\mathrm{y}=\mathrm{Ak}^{\alpha}$ where $\mathrm{y} \equiv$ income per worker, $\mathrm{k} \equiv$ capital labor ratio, and $0<\alpha<1$. The shift variable $A=\varphi T^{\beta} \mathrm{e}^{\gamma}$ is a function of the trade index $T \equiv(X+M) / Y$ and the exchange rate $\mathrm{e} \equiv \mathrm{bath} / \mathrm{S}$.

In $\log$ linear form $\ln y=\ln \mathrm{A}+\alpha \ln \mathrm{k}=$ $\ln \varphi+\beta \ln T+\gamma \ln e+\alpha \ln k$ and the empirical specification is

$\ln y_{t}=a_{0}+a_{1} \ln T_{t}+a_{2} \ln e_{t}+a_{3} \ln k_{t}+\varepsilon_{t}$

Where $\varepsilon_{\mathrm{t}}$ is a stochastic error term. Coefficient $\mathrm{a}_{3}$ is the capital share of output and expected to be positive and less than one. There are no a priori expectations about the signs of $\mathrm{a}_{1}$ and $\mathrm{a}_{2}$.

\section{Data and stationarity analysis}

The 51 annual observations from 1950-2000 are from Penn World Table 6.1 of Heston, Summers, and Aten (2001). Trade is in current prices, the 1996 USD value of the sum of exports and imports divided by GDP as in Ades and Glaeser (1999), Frankel and Romer (1999), Alesina, Spolaore, and Wacziarg (2000), and Frankel and Rose (2002). Capital is derived as accumulated investment starting with 1950 investment as the capital stock that year. Time plots are in Figure 1.

Stationarity tests are reported in Table 1 . The variables are not stationary in autoregressive (AR1) models. The variable lnk is not difference stationary in the augmented Dickey-Fuller (ADF) test. The F-value in the ADF model is larger than the critical $\varphi$ statistic (5.61) and lnk is not a random walk but the white noise residual from the ADF model resk $=$ $\mathrm{dlnk}_{\mathrm{t}}-0.50 \mathrm{dln}_{\mathrm{t}-1}$ qualifies for regression analysis.

The variables $\ln \mathrm{Y}$ and $\ln \mathrm{T}$ are difference stationary with in DF models with white noise residuals. Variable lne is not difference stationary, does not pass the $\mathrm{ADF}$ test, and cannot be detrended because 
residuals do not have constant variance. Transformed to the double $\ln$ form, lnlne is not stationary but is difference stationary in the DFt model with a time trend. The regression model uses lnlne as the exchange rate variable.

In summary, $\ln y, \ln \mathrm{T}$, and $\ln \operatorname{lne}$ are random walk integrated $\mathrm{I}(1)$ processes and their first differences enter in model construction. The residual of $\operatorname{lnk}$ in the ADF model (resk) is used to examine the effect of the capital labor ratio variable.

\section{Model construction and estimation}

As apparent in Figure 1, there is a structural break in 1980 in the exchange rate and a dummy variable (D) is included with $\mathrm{D}=0$ for $1950-1980$ and $\mathrm{D}=1$ after 1981.

In the regression, dlny is the dependent variable and $\mathrm{d} \operatorname{lnT}$, resk, and dlnlne are explanatory variables. The variable resk is replaced by its regression $\operatorname{resk}_{t}=\mathrm{dlnk}_{\mathrm{t}}-0.50 \mathrm{dlnk}_{\mathrm{t}-1}$ in the ADF model.

The empirical model is then

$\mathrm{dlny}=\alpha_{0}+\alpha_{1} \mathrm{dln} \mathrm{T}+\alpha_{2}$ resk $+\alpha_{3} \mathrm{dln} \ln \mathrm{e}+$ $\alpha_{4} \mathrm{D}+\alpha_{5} \mathrm{DdlnT}+\alpha_{6}$ Dresk $+\alpha_{7} \mathrm{Ddlnlne}+\varepsilon_{\mathrm{t}}(2)$

Regression results are in Table 2. The autocorrelation in model $\mathrm{A} 0$ is controlled in model A with Prais and Winsten algorithm in Limdep.

For description, Model A is written in the two periods as

$\mathrm{dlny}_{\mathrm{t}}=0.07-0.16 \mathrm{dln} \mathrm{T}_{\mathrm{t}}+1.44 \mathrm{resk}_{\mathrm{t}}$ $+1.23 \mathrm{~d} \ln \ln \mathrm{e}_{\mathrm{t}}(1950-1980)$

$\mathrm{dlny}_{\mathrm{t}}=0.07+0.07 \mathrm{dln}_{\mathrm{t}}+1.44 \mathrm{resk}_{\mathrm{t}}$ - 0.65dlnlne $e_{t}(1981-2000)$

Substituting $\mathrm{dlnk}_{\mathrm{t}}-0.50 \mathrm{~d} \ln \mathrm{k}_{\mathrm{t}-1}$ for resk $_{t}$ the derived model is

$\mathrm{dln}_{\mathrm{t}}=0.07-0.16 \mathrm{~d} \ln \mathrm{T}_{\mathrm{t}}+1.44 \mathrm{dlnk}_{\mathrm{t}}-$

$0.72 \mathrm{dlnk}_{\mathrm{t}-1}+1.23 \mathrm{dln}_{\ln \mathrm{e}_{\mathrm{t}}(1950-1980)}$

$\mathrm{dlny}_{\mathrm{t}}=0.07+0.07 \mathrm{dln}_{\mathrm{t}}+1.44 \mathrm{dln}_{\mathrm{t}}-$ $0.72 \mathrm{dlnk}_{\mathrm{t}-1}-0.65 \mathrm{dlnln} \mathrm{e}_{\mathrm{t}}(1981-2000)$
General-to-specific modeling is applied to the reduced models to test respective hypotheses as in Table 2 . In model $\mathrm{B}$, the hypothesis of no level or slope effect $\left(\alpha_{4}=\alpha_{5}=\alpha_{6}=\alpha_{7}=0\right)$ is tested and the $F$ test indicates rejection of this null hypothesis. The hypothesis of no level effect $\left(\alpha_{4}=0\right)$ cannot be rejected in model $\mathrm{C}$ while the null hypothesis of no structural effect $\left(\alpha_{5}=\alpha_{6}=\alpha_{7}=0\right)$ is rejected in model $\mathrm{D}$ ensuring the dummy variable is appropriate.

\section{Results}

The role of capital is confirmed with an elasticity $\varepsilon_{\mathrm{yk}}=\delta \operatorname{lng}_{\mathrm{t}} / \delta \operatorname{lnk}_{\mathrm{t}}+\delta \ln \mathrm{y}_{\mathrm{t}} /$ $\delta \operatorname{lnk}_{\mathrm{t}-1}=1.44-0.72=0.72$ from (5) and (6) across the structural break. Every 1\% increase in the capital/labor ratio raises per capita income by $0.72 \%$ making the estimated factor share of capital in the modified Cobb-Douglas production function 0.72 . The restriction of no capital effect $\left(\alpha_{2}=\alpha_{6}=0\right)$ is imposed to ensure the effects of trade and the exchange rate are not dominated by the capital/labor ratio, a suspected dominant variable. The F statistic 7.75 with capital restricted confirms the significant effects of trade and the exchange rate.

Elasticities of the exchange rate and trade are derived from (5) and (6). To ensure significant effects, general least square regression with constraints is imposed in model $\mathrm{E}$ with no trade effect and model $\mathrm{G}$ with no exchange rate effect. The exchange rate effect is confirmed in model $\mathrm{G}$ with that $\mathrm{F}$ statistic. Using the average lne during the entire period of 3.13 , the elasticity of the exchange rate prior to 1980 is $1.23 / 3.13=0.392$ with dlny/dlnlne $=\ln e^{*} \mathrm{dlny} / \mathrm{dlne}=1.23$ and $\mathrm{dlny} / \mathrm{dlne}=$ $1.23 /$ lne. Devaluation by $10 \%$ would have raised per capita income by $3.9 \%$ prior to 1980 but since then a $10 \%$ depreciation would lower per capita income $2.1 \%$. 
These estimated exchange rate effects seem reasonable. There were two periods of high exchange rate variation during the oil price shock of 1979-1980 and the Asian financial crisis of 19971999. Devaluation in 1980 is considered a cause of the considerable increase in trade, while depreciation was more a symptom of the financial crisis. Along with policy focusing on export promotion in the 1980s, the structural break in 1980 is verified by the dummy variable DdlnT. Depreciation has been thought to contribute to export recovery following the financial crisis. Athukorala and Suphachalasai (2004) believe the growth of trade of parts and components in vertically integrated production has weakened the exchange rate effect.

To test the effect of trade on per capita income, the restriction $\alpha_{1}=\alpha_{5}=0$ is imposed with the hypothesis of no trade effect. This hypothesis cannot be rejected with an $\mathrm{F}$ test in model $\mathrm{E}$ indicating no effect of trade over the entire period. Looking at the two periods separately, trade had a small negative impact prior to 1980 and a very small positive impact since then. Prior to 1980 , an increase of $10 \%$ in trade lowers per capita income by $1.6 \%$ in $(5)$.

Prior to 1980, Thailand was a small resource based country with exports directed to larger developed countries such as the US and Japan. Agricultural products suffered declining prices relative to imports of capital machinery, transport goods, and crude oil. With the oil shocks of 1973 and 1979, the net value of Thai oil imports rose from \$53 million in 1970 to $\$ 685$ million in 1982 and dependence on foreign oil reached $75 \%$ in 1980 . Oil imports must contribute to the negative effect of trade on growth before 1980 .

After 1980, the effect of trade changes with a $10 \%$ increase in trade raising per capita income by $0.7 \%$ consistent with the shift to manufactured exports. Although Thailand has a trade surplus in recent years as shown in Figure 2, efforts to increase exports only offset increasing import demand. The terms of trade declined steadily from 102 in 1982 to 77 in 2003 suggesting the increased export revenue only offsets rising import prices. Adams, Ichino and Prazmowski (2000) use an energy balance model to find that growth in Thailand is based on export promotion, with foreign earnings offsetting the cost of imported fuel.

Vohra (2001) finds exports have a positive impact on economic growth when a country achieves some level of development, examining India, Pakistan, the Philippines, Malaysia, and Thailand from 1973 to 1993. Lee and Pan (2000) find little evidence of Granger causal relations from exports to GDP in Hong Kong, Indonesia, South Korea, Malaysia, the Philippines, Singapore, Taiwan, and Thailand. Ekanayake (1999) uses cointegration and error-correction models to confirm there is no strong evidence of short run causality from export growth to economic growth in India, Indonesia, Korea, Malaysia, Pakistan, Philippines, Sri Lanka and Thailand. Siddique and Selvanathan (2002) use cointegration and Granger causality tests to examine relationships between exports, imports, and economic growth in Thailand during 1953-1993 finding growth causes exports, imports cause growth, and exports cause imports. These studies, however, do not include the foundation of growth theory or control for the exchange rate as in the present paper.

The growth effect of capital accumulation is affirmed in models (5) and (6). Thai development may have been based on capital accumulation from agriculture but Yamada (1998) 
finds investment flows from agriculture have not been large. Since the 1970s the government has adopted an export oriented policy emphasizing labor intensive light manufacturing and investment has created rural jobs. Manufacturing has been effective in boosting the economy since the 1980s.

Marwah and Tavakoli (2004) find one fifth of capital productivity in Thailand was generated by foreign investment from the early 1970 s to 1998. Vohra (2001), Kohpaiboon (2003), and Marwah and Tavakoli (2004) emphasize the role of foreign investment in Thailand. Imports in the present study include capital goods typically linked to foreign investment. The present paper shows the importance of investment and increased trade during the period of manufactured exports.

\section{Conclusion}

The theoretical role of investment and capital is confirmed by the present time series growth model that controls for the effects of the exchange rate and trade during the last half of the $20^{\text {th }}$ century in Thailand. The present results call into question estimates of the links between trade and growth that omit capital input.
The exchange rate has opposite effects on growth depending on the exchange rate regime. Devaluation raises per capita income before 1980 under the fixed exchange rate regime but depreciation of the floating baht since then lowers growth. Devaluation of a fixed exchange rate does not appear to be successful in stimulating trade but depreciation of a floating exchange rate does.

Trade had a negative effect on Thai per capita income prior to 1980 during the years of a resource based economy with import substitution policy. With the emergence of manufactured exports since 1980 trade has had a very small positive impact growth.

\section{Acknowledgment}

The comments from Professors Henry Thompson and Henry Kinnucan (Auburn University, AL, USA) are invaluable to improve this manuscript. The author also appreciates participants in the Twelfth Annual International Conference on Statistics, Combinatorics, Mathematics and Applications for helpful comments. Responsibility for final content, however, rests strictly with the author.

\section{REFERENCES}

Adams, F.G., Y. Ichino, and P.A. Prazmowski (2000) Economic Growth and Energy Import Requirements: An Energy Balance Model of Thailand, Journal of Policy Modeling, 22(2), pp. 219-54.

Ades, A. and E.L. Glaeser, 1999, Evidence on Growth, Increasing Returns, and the Extent of the Market, Quarterly Journal of Economics, 114, pp. 1025-45.

Alesina, A., E. Spolaore and R. Wacziarg, 2000, Economic Integration and Political Disintegration, American Economic Review, 90(5), pp. 1276-96.

Alesina, A., E. Spolaore and R. Wacziarg, 2003, Trade, Growth and the Size of Countries, Harvard Institute of Economic, Research Discussion Paper, 1995, Cambridge, MA. Asian Development Bank, 2004, Key Indicators, online, June 2005.

Athukorala, P. and S. Suphachalasai, 2004, Post-crisis Export Performance in Thailand, 
ASEAN Economic Bulletin, 21(1), pp. 19-36.

Deme, M. and H. Ghassem, 2001, Openness and Economic Growth in Japan and South Korea: An Empirical Investigation, Economia Internazionale, 54 (2), pp. 163-75.

Dowrick, S. and G. Jane, 2004, Trade Openness and Growth: Who Benefits?, Oxford Review of Economic Policy, 20 (1), pp. 38-56.

Ekanayake, E. M., 1999, Exports and Economic Growth in Asian Developing Countries: Cointegration and Error-Correction Models, Journal of Economic Development, 24(2), pp. 43-56.

Ender, W., 2004, Applied Econometric Time Series, $2^{\text {nd }}$ ed., John Wiley and Sons, Inc.

Frankel, J.A and E.A. Cavallo, 2004, Does Openness to Trade Make Countries More Vulnerable to Sudden Stops, Or Less? Using Gravity to Establish Causality, NBER Working Papers, 10957, National Bureau of Economic Research.

Frankel, J. and D. Romer, 1999, Does Trade Cause Growth? American Economic Review, 89(3), pp. 379-99.

Frankel, J. and A. Rose, 2002, An Estimate of the Effect of Common Currencies on Trade and Income, Quarterly Journal of Economics, 117(2), pp. 437-466.

Fullbright Economic Teaching Program. 2002, Globalization, Saigon Times Daily, Dec. 23, Vietnam.

Heston, A., R. Summers, and B. Aten, 2001, Penn World Table 6.1. Universiry of Toronto Canada, online, June 2005.

Karras, G., 2003, Trade Openness and Economic Growth: Can We Estimate the Precise Effect? Applied Econometrics \& International Development, 3(1), pp 7-26.

Kohpaiboon, A., 2003, Foreign Trade Regimes and the FDI-Growth Nexus: A Case Study of Thailand, Journal of Development Studies, 40(2), pp. 55-69.

Lee, D.Y. and M.S. Pan, 2000, On Exports and Economic Growth in East Asian Countries: Linear and Nonlinear Causality Analyses, Pennsylvania Economic Review, 9(2), pp. 66-78.

Levine, R. and D. Renelt, 1992, A Sensitivity Analysis of Cross-Country Growth regressions, American Economic Review, 82(4), pp. 942-963.

Lutz, J.M., 2001, Growth of Industrialized Countries and Trade Openness, International Trade Journal, 15(4), pp. 429-55.

Marwah, K. and A. Tavakoli, 2004, The Effect of Foreign Capital and Imports on Economic Growth: Further Evidence from Four Asian Countries (1970-1998), Journal of Asian Economics, 15(2), pp. 399-413.

Masters, W. and M. McMillan. 2001, Climate and Scale in Economic Growth, Journal of Economic Growth, 6(3), pp. 167-186.

McCarthy, F.D., L. Taylor and C. Talati, 1987, Trade Patterns in Developing Countries, 1964-1982, Journal of Development Economics, 27(1-2), pp. 5-39.

Olufemi, S.M., 2004, Trade Openness and Economic Growth in Nigeria: Further Evidence on the Causality Issue, Suid-Afrikaanse Tydskrif vir Ekonomieseen Bestuurswetenskappe/South African Journal of Economic \& Management Sciences, 7(2), pp 299-315. 
Panagariya, A., 2004, Miracles and Debacles: In Defence of Trade Openness, World Economy, 27(8), pp 1149-71.

Rassekh, F., 1992, The Role of International Trade in the Convergence of per Capita GDP in the OECD: 1950-1985, International Economic Journal, 6(4), pp 1-15.

Sala-i-Martin, X., 1997, I Just Ran Two Million Regressions, American Economic Review, 87(2), pp. 178-183.

Siddique, M. A. B. and E.A. Selvanathan, 2002, Export Performance and Economic Development in Thailand, Empirical Economics Letters, 1(1), pp. 33-42.

The Economist, 2004, Country Briefings - Thailand Economic Structure, [online; cited June 2005] Available from URL:

$\mathrm{http}$ //www.economist.com/countries/Thailand/profile.cfm?folder=Profile\%2DEconomic\%20Structure.

Thompson, Henry. 2001. International Economics - Global Markets and International Competition. World Scientific Publishing Co. Pte. Ltd., Singapore.

Vohra, R., 2001, Export and Economic Growth: Further Time Series Evidence from Less-Developed Countries, International Advances in Economic Research, 7(3), pp. 345-50.

Yamada, J., 1998, Capital Outflow from the Agriculture Sector in Thailand. Policy Research Working Paper, 1910. The World Bank. 


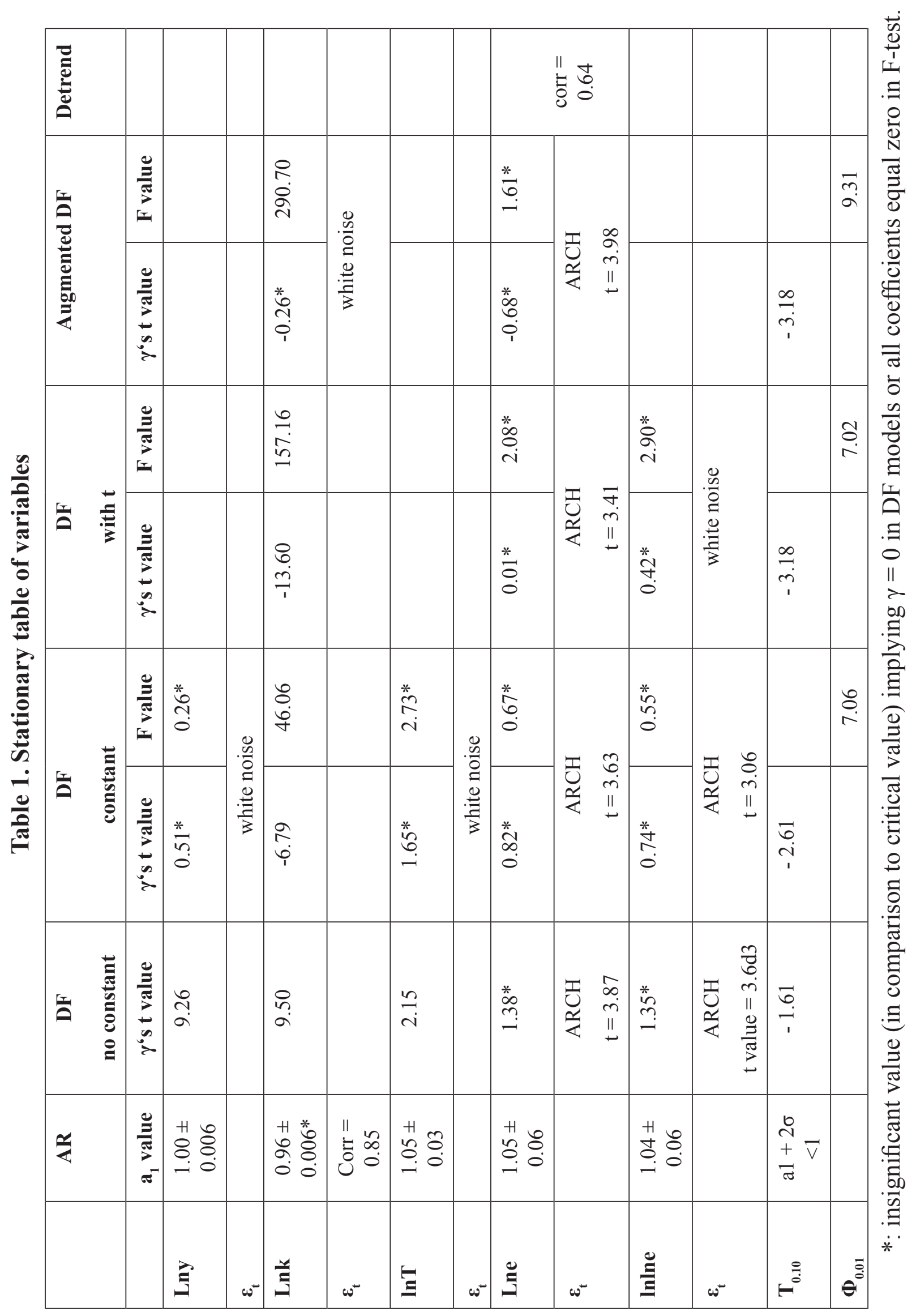




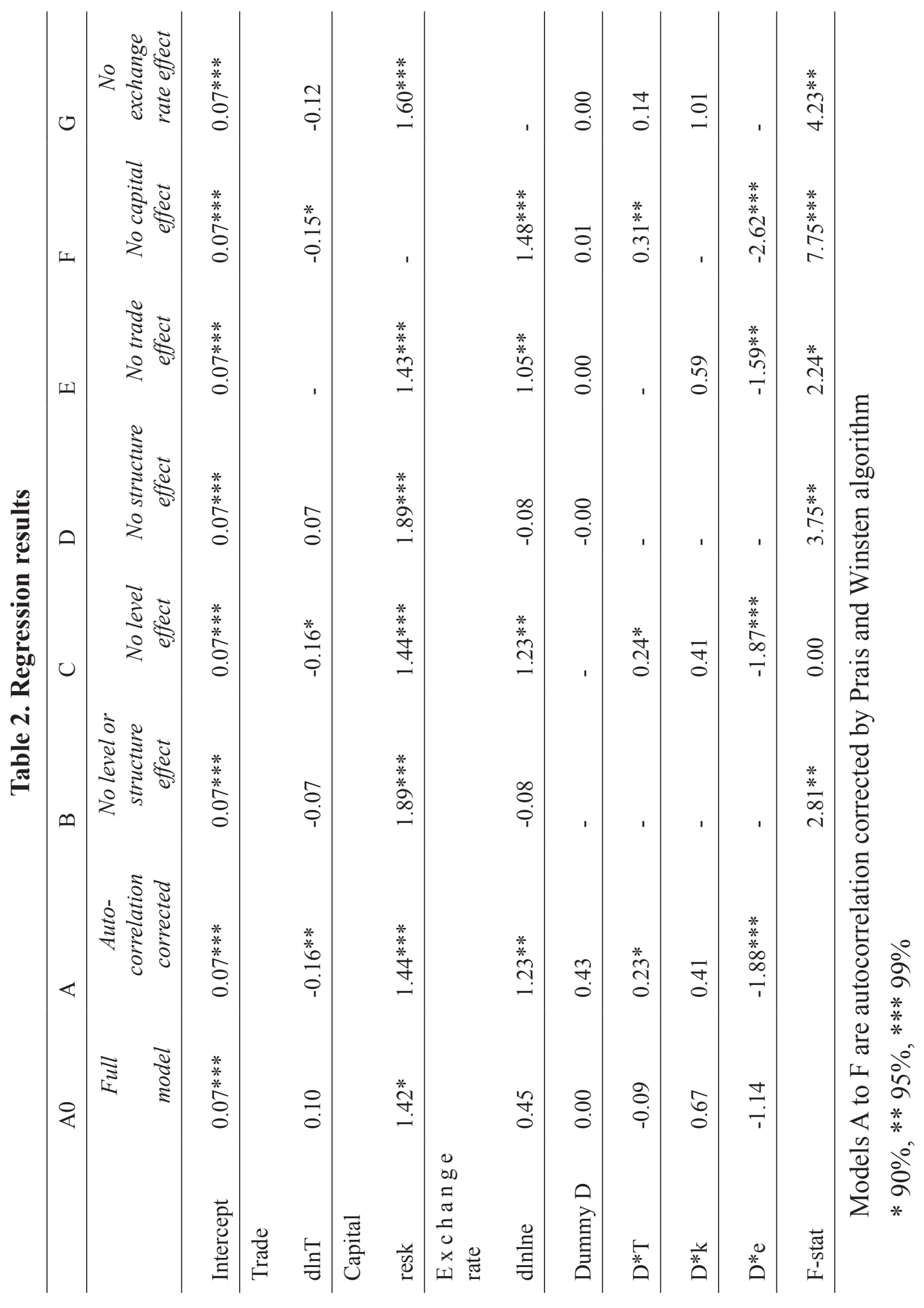


Figure 1. Time trend of variables

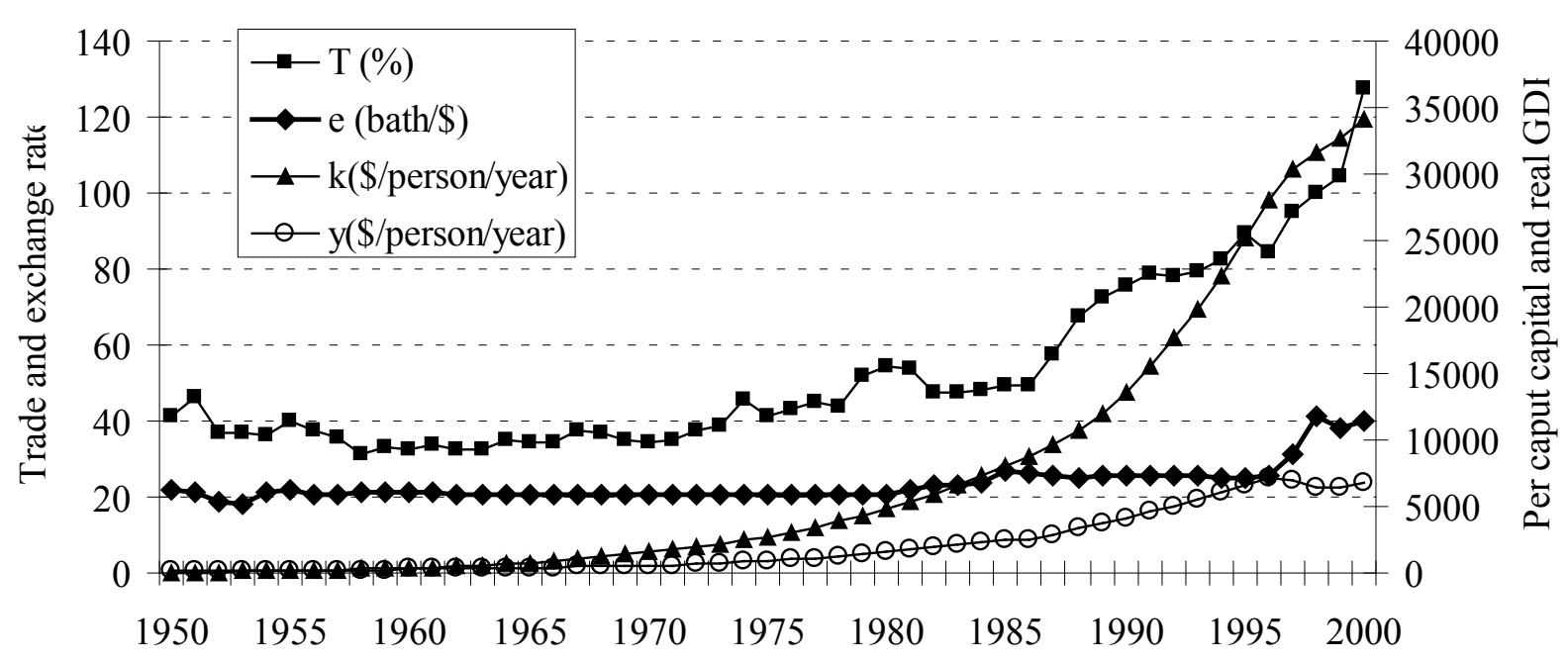

Figure 2. International trade of Thailand 1981-2003 (million bath) Source: ADB

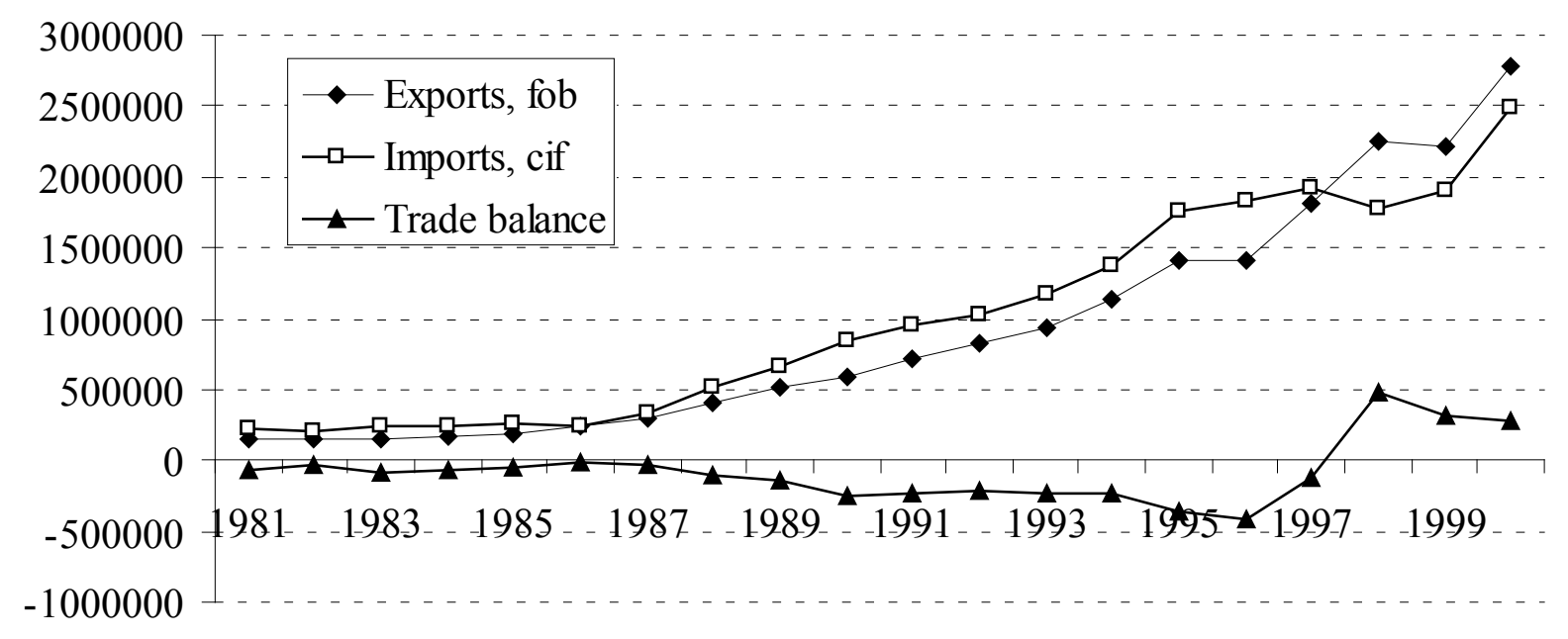

